\title{
Business incubator managers' perceptions of their role and performance success: role demands, constraints and choices
}

Article

Accepted Version

Kakabadse, N., Karatas-Ozkan, M., Theodorakopoulos, N., McGowan, C. and Nicolopoulou, K. (2020) Business incubator managers' perceptions of their role and performance success: role demands, constraints and choices. European Management Review, 17 (2). pp. 485-498. ISSN 1740-4762 doi: https://doi.org/10.1111/emre.12379 Available at https://centaur.reading.ac.uk/87353/

It is advisable to refer to the publisher's version if you intend to cite from the work. See Guidance on citing.

To link to this article DOI: http://dx.doi.org/10.1111/emre.12379

Publisher: Wiley

All outputs in CentAUR are protected by Intellectual Property Rights law, including copyright law. Copyright and IPR is retained by the creators or other copyright holders. Terms and conditions for use of this material are defined in the End User Agreement. 


\section{CentAUR}

Central Archive at the University of Reading

Reading's research outputs online 
Article title: Business Incubator Managers' Perceptions of their Role and Performance Success: Role Demands, Constraints, and Choices

Short Tittle: Business Incubator Managers

\author{
Nada K. Kakabadse \\ Professor of Policy, Governance and Ethics \\ Henley Business School \\ Greenlands Henley on Thames RG9 3AU \\ +44(0)1491 418786 \\ n.kakabadse@ reading.ac.uk \\ (corresponding author) \\ Mine Karatas-Ozkan \\ Chair in Strategy and Entrepreneurship| \\ Southampton Business School \\ University of Southampton \\ Southampton SO17 1BJ \\ Tel: +44 (0)2380598971 \\ E-mail: mko@soton.ac.uk \\ Nicholas Theodorakopoulos \\ Professor of Entrepreneurship Development \\ Aston Business School, \\ Birmingham, \\ +44(0)1212043472 \\ n.theodorakopoulos@aston.ac.uk \\ Dr Carmel McGowan \\ Senior Tutor in Business Systems \\ Strategy and Management \\ University of Bedfordshire University \\ carmel.mcgowan103@gmail.com \\ Dr. Katerina Nicolopoulou \\ Hunter Centre for Entrepreneurship \\ University of Strat Clyde \\ katerina.nicolopoulou@strath.ac.uk
}

No potential conflict of interest. 


\title{
Business Incubator Managers' Perceptions of their Role and Performance Success: Role Demands, Constraints and Choices
}

\begin{abstract}
Using Stewart's (1976) role framework as an analytical lens, this paper examines how business incubator managers perceive their role and performance, and the choices they make in dealing with constraints and competing demands. Given that the literature in this domain has not considered how these types of managers experience agency and structure in their role, this study is important in theory and practice terms. Drawing on 40 qualitative interviews in different UK regions, the findings demonstrate the ways in which business incubator managers see their role as pivotal in supporting the incubatee entrepreneurs and how they endeavour to address competing role demands against constraints. Notably, while funding is commonly viewed as an enabler, the findings suggest that the funding structure could act as a constraint on the incubator managers, due to the weight of perceived bureaucracy preventing the latter from operating effectively within the full remit of their role.
\end{abstract}

\section{Introduction and research gap}

Growing body of literature argues that the business incubation can support the development of business skills, networks, access to coaching and mentoring, along with providing a wide range of support services in order to help the incubatee entrepreneurs take their business forward, and minimise the risk of potential failure setting (Al-Mubaraki and Busler, 2013; Barrow, 2001; McAdam and Marlow, 2007; Wonglimpiyarat, 2016; Zhang, Wu, and Zhao, 2016). In that regard, the incubator manager-incubatee relationship is critical in adding value (Autio and Klofsten. 1998; Fry, 1987; Sherman, 1999; Udell, 1990), with a number of studies (for example, 
Hackett and Dilts, 2004; Lalkaka, 2002) specifically acknowledging the incubator manager as the key success factor for business start-ups. Research has also shown the significance of the incubator manager in attracting suitable incubatee entrepreneurs and assisting them as their business develops, while handling the funders' compliance requirements (Meru and Struwig, 2015; Prokopenko and Pavlin, 1991; Rouach et al., 2010). Nonetheless, the literature, apart from a few exceptions (Allen and Bazan, 1990; Duff, 2000; Patton, 2014), offers little in-depth investigation of the incubator manager's role in impacting the start-up's success or failure. Moreover, researchers have paid little, if any, attention to the individual incubator manager's perception of their role in performance success and how they attempt to deal with job demands and constraints in fulfilling their role. This represents a significant gap in knowledge.

Given the importance of the topic and dearth of studies in this area, our approach generates two interrelated research questions: first, how do incubator managers perceive their role, and performance success? Second, how do incubator managers deal with perceived job demands and constraints? In order to address the above, the paper examines how the incubator managers perceive their role and performance success, while working through their role demands, constraints, and choices, using Stewart's (1976a; 1976b; 1997) demands, constraints and choices (DCC) model as an analytical lens. We make three main contributions to knowledge in this field. First, we address the gap by shedding light on the interaction of individual and organisational processes in terms of business incubation, and enrich our understanding of the relational aspects that highlight the previously understated role of the individual incubator manager. Second, drawing on empirical evidence, we examine the nature of the incubator manager's role in the process, being the first to apply role theory (Stewart, 1982) in entrepreneurship research, and more specifically in the field of business incubation management. Using role as a way of conceptualizing 
work performance, we offer a theoretically-based model of incubator managing work roles, contributing to the view of incubator managers' performance from this perspective. Third, we offer policy implications for the institutions of wider entrepreneurial ecosystems that are charged with developing incubation programmes. We provide empirical evidence of the management challenges that incubator managers face, which represent specific critical barriers that, if removed, would help solve important problems in business incubation.

The rest of the paper is organised as follows: we begin by outlining the extant literature on business incubators and the role of managers. We then explain the theoretical framework underpinning the research. We move on to present the methodology, followed by the findings section, which is structured around four themes. The discussion section presents our interpretation of findings by revisiting the theoretical framework and literature. We finally draw some conclusions, addressing the research questions set and highlighting contributions and potential for future research.

\section{Mapping out the business incubator manager role}

Business incubators have been instrumental across the globe for spinning out entrepreneurial activity (Albort-Morant and Ribeiro-Soriano, 2016; Calza et al., 2014; Clarysse et al., 2005). These organisations are often characterised by their objective of nurturing early stage entrepreneurs and start-up activities (Dutt et al. 2016; Phan et al., 2005; Rothaermel and Thursby, 2005). Relevant literature has mainly focused on developed economies, and the emphasis has on been the outcome of new enterprise creation. There is, however, another strand of work that has captured the process elements of incubation (Ahmad, 2014; Karatas-Ozkan et al., 2005; Theodorakopoulos 
et al., 2014). What is more interesting recently is that the institution-building activities of business incubators have been brought to the fore (Siegel and Wright, 2015), particularly in the context of weak institutional environments whereby governments, universities, and relevant private sector institutions are not able to create such ecosystems for incubation. In Tocher et al.'s (2015) work, social resources are viewed as an important part of the opportunity creation process; incubators could act here as intermediary organisations, particularly helping incubatee entrepreneurs in tackling uncertainty reduction in the early phases of their venturing process.

As institution-building intermediary organisations, how incubators function is an important dimension pertaining to the current study. Their functioning and internal management processes are contingent upon the interface in the micro-level context of human relations (within the incubator, including managerial relationships) with the wider macro-context of structural dynamics, such as regional economy, public policy, and entrepreneurship culture (Ahmad, 2014). Relatively recent work underpinned by institutional theory (Battilana et al., 2009), is concerned with the role of individuals in institutional change, in the way that their roles are defined and conditioned by the very structures of the institutions they create and work for. These institutional settings can both enable as well as constrain their agency.

This involves, in essence, two phenomena: one is the institution-building activity and impact that it creates; the other is the challenge of legitimacy, which is circumscribed by the tension of novelty and compliance. Incubators as organisations are created to serve the purpose of nurturing new entrepreneurial activity; therefore, their remit and functioning is aligned with refining existing structures in novel and creative ways. Desa and Basu (2013), for example, highlight different strategies for overcoming resource constraints in the context of social entrepreneurship; if incubators are viewed as legitimate and worthy institutions, the incubation process can have a 
transformative effect on the wider ecosystem. On the other hand, as part of wider innovation and entrepreneurship ecosystems, their activities need to be legitimised visà-vis the funding organisations, the institutions that create these structures. Incubator managers have a challenging role in terms of reconciling the more bureaucratic procedural duties with those of supporting the incubatee entrepreneurs (Duff, 2000). How entrepreneurs and managers navigate between the enabling and constraining forces of the macro and meso-institutional environments (De Castro et al., 2014) is an important consideration in this regard. Notably, their agency is influenced by how they perceive their role as managers and what they see as legitimate ways to deal with structural arrangements, often relating to job demands and constraints.

In the context of business incubation management in particular, despite the recognition of the significance of the incubator manager in the literature, research on how incubator managers perceive their role and how their perception shapes their approach to competing demands and constraints is scarce (Theodorakopoulos et al., 2014). Hence, our paper focuses on the way in which incubator managers respond to competing demands in their job role, emanating from institutional arrangements that reflect a particular stakeholder-mix. These requirements often entail dealing with competing logics in the context of incubation. For example, they need to address the diverse needs of incubatee entrepreneurs, as well as responding to the demands of funders and other stakeholders, such as government or public organisations. Examining these dimensions in more detail, in this paper we demonstrate how business incubator managers perceive their role and how they go about dealing with constraints and reconciling competing demands.

\section{Analytical Lens}


Role in an organisation has generally been defined as the pattern of behaviour associated with an individual occupying a particular position or job within the structure of the organisation (Katz and Kahn, 1978; Mullins, 2002; Shivers-Blackwell, 2004). Role theory has been used by researchers in psychology, sociology, organizational behaviour, and human resource management. This theory allows context to be taken into account, by identifying, for example, constraints arising from the context in which the role is enacted, including the physical spaces within which the incumbent operates, as well and social and cultural norms (Fondas and Stewart, 1994). Previous managerial role-focused studies revealed that individuals are not merely passive recipients of role expectations, but that they are actively involved in shaping their own role (Biddle and Thomas, 1979; Fondas and Stewart, 1994; Willcocks, 1994). Willcocks (1994) posits that roles are not static, but change as individuals interact together. Troyer et al. (2000, p.413) argue that the "role corresponding to a position always has the potential to be made by the occupant of the position."

In order to understand incubator manager role requirements, the present study adopts Rosemary Stewart's theoretical framework (Stewart, 1982), which is the role demands-constraints-choices model. Stewart (1982) model is deemed a potent lens in identifying the challenge of praxis, ethos, and philosophy in terms of managerial demands, choices, and constraints (DCC) in the context of business incubation management. The DCC model introduces the concept of role making which assumes that individuals are not simply reactive to other individuals' expectations, but also enact their own roles. "Whilst role taking is about how the focal person perceives role expectations and acts upon them, role making is about the focal person attempting to create and/or change role expectations and communicate those to the role senders." (Petrovic, 2008, p. 1375). Stewart (1982) believes that in order to understand managerial roles, one must understand the flexibility offered by the role, and that 
although there are some common elements of flexibility in managerial roles, there are significant differences in "the opportunities that managerial jobs offer for one jobholder to behave differently from another." (Stewart, 1982, p. 11).

In Stewart's (1982) model, demands represent what "anyone in the job has to do." In other words, they are the activities that are part of the role remit or are imposed by management that a manager must do as part of their role. Constraints are the tangible or intangible factors (such as finance or attitude) which limit what the manager can do (Stewart, 2003). Stewart (1982) argues that individuals in managerial positions are faced with activities that they can do, but do not have to if they are not willing to do so, whilst managers have choices and opportunities to "do different work, from [one] another and to do it in different ways." (Stewart, 1982, p. 9). Kroeck (2003) noted that managers have, for instance, the choice of determining how to perform their role, how much they can delegate and how much they are willing to observe organisational boundaries. As Stewart (1982) stresses, choices are only limited by constraints and demands, but these can change over time, and be influenced by the manager. However, Fondas and Stewart (1994) recognise that not every manager engages in role-making, and that not every role set would allow individuals to do so.

According to Stewart (1982), it is the relevance of choices that the role-holder exercises to the situation at hand that determines leadership effectiveness. Stewart (1982) describes these choices as (1) what aspects of the job the manager chooses to emphasise in terms of time, effort, and commitment of resources; (2) how and what tasks are delegated; and (3) how the manager manages his/her job boundaries. The role set of an individual consists of the different people with whom a manager interacts and "who have a stake in and hold expectations about the manager's performance in the job" (Fondas and Stewart 1994, p. 86). Although Stewart did not conceive the model 
to place particular focus on incubator managers, we use the identified constructs of this theoretical framework in the present paper in order to discuss the findings from the primary research that we conducted with 40 incubator managers in the UK.

\section{Methodology}

The purpose of this study is to gain an in-depth understanding into how incubator managers perceive their role and performance, and how they endeavour to deal with competing role demands and constraints. In order to meet this aim, the researchers adopted a qualitative case study approach (Crowe et al., 2011; Gomm et $a l ., 2002)$. Qualitative case study research of this nature attempts to explain reality as experienced by the participants (incubator managers) in a reflective manner. Adopting in-depth, semi-structured interviews allowed us, as researchers, the freedom to probe beyond the specific questions in order to allow the incubator managers time and scope for reflection. We collected the data through interviews, direct observations, company documents, and business incubator websites (Barratt et al., 2011) and analysed them applying a thematic qualitative data analysis technique, subsequently leading to interpretation and theorising (Miles and Huberman, 1994).

The geographic location of this study included England, Wales, Scotland, and Northern Ireland (that is, the United Kingdom) and was based on 40 case studies of incubator managers. The selected 40 business incubation centres were spread evenly across the UK. For each of the selected regions (see Figure 1) the researchers interviewed the incubator manager (see Table 1). In this way, we could investigate and compare each of the incubator manager's incumbent roles to comprehensively understand them and to support validity and generalizability claims. 
[Insert Figure 1]

[Insert Table 1]

We conducted all the interviews, which lasted between one and two hours, at the business incubator sites. All interviews were recorded and supplemented with hand-written notes. We transcribed the interviews in full and imported them into NVivo to help with data management and analysis. Role analysis (Stewart, 1982) was used as part of the study methodology, providing an initial, flexible framework for examining the constraints, challenges, and choices that incubator managers faced when enacting their roles. This in turn allowed us to identify the perceived tensions and responses to tensions produced by role incumbents in their particular contexts, as well as allowing new themes to emerge from the data. In accord with Bika and Kalandaridis (2017), as a result of taking a critical realist perspective, replication and propositionbuilding were not condemned by default as belonging to positivism and therefore at odds with our qualitative study.

An important criterion of this study was to identify the perception of success. The literature indicated that the incubator manager and incubatee entrepreneur have different perceptions within the relationship, and therefore term success differently. The incubator managers' individual perceptions were the main focus of the present study, and therefore their definition of success prevailed. In line with the critical realist perspective, the authors adopted an inter-subjective lens for investigating each incubator manager's perception of his or her role. If the incubator manager met his or her expectations, then we viewed them as having met their perceived performance success (see Figure 2). This is the incubator managers own assessment of their success despite all of them having meet their targets set by their funding body and this applies to the last reporting period to the date of interview. 
[Insert Figure 2]

\section{Findings}

The analysis of transcribed data forms the basis for thematic investigation of the incubator managers' demands, constraints, and choices within their role. We first sorted and coded the transcribed scripts within a predefined thematic framework based on Stewart's (1976a; 1976b) theory of role demands, constraints, and choices (see Table 2).

[Insert Table 2]

We examined responses within each framework's theme concerning the incubator managers' views, allowing contrast and comparison across regional scripts. The analysis identified an emerging critical theme across all regions that the incubator managers perceived business incubator services as target-driven, and primarily following an ongoing pressure to meet occupancy targets. This could impact on the likelihood of incubatee entrepreneurs acquiring admission to the incubators. The following section further discusses the incubator managers' perceptions, as identified through the research themes.

\section{Theme 1: the incubator managers' primary role}

The incubator managers perceived their role as a support mechanism that added value to the incubatee entrepreneurs and enabled the start-up businesses to survive and 
grow. Table 3 provides an overview in terms of how the incubator managers perceived their role.

[Insert Table 3]

Responses from Table 3 clearly indicated the incubator managers' motivation and commitment to their role. The data further revealed that they tended to perceive themselves as a support mechanism in place to help and grow the incubatee entrepreneurs and their businesses. They talked at length about their own personal motivations towards the role and the positive contribution they brought to the incubatee entrepreneurs. One manager expressed, "The environment that I've created is very nurturing and supportive and it's this that they need to fast track their success." (IM4) The level of enthusiasm that the incubator managers displayed towards their role was very encouraging, despite the many role demands and constraints that they faced. It was inspiring to note that all incubator managers acknowledged support of the incubatee entrepreneurs as being their primary objective.

It was evident from the interviews that the incubator managers felt strongly that their role was not that of a "landlord" or "target achiever". They affirmed that their primary role was not to collect rent from the incubatee entrepreneurs, meet targets and/or secure funding, which is an indication of their active agentic capacity. The following transcript excerpts outline this point:

"I hate to use that expression, but we're not here just to rent property, but to signpost entrepreneurs about programmes. We're here to get involved with them, to try and understand and have some empathy as to what else they need." (IM33) 
"I'm not a landlord to collect the rent once a month... I'm here to support and see these businesses accelerate and reach their desired goals... if I'm not doing my primary role I'm just wasting my time as I'm not performing my responsibility that I'm being paid to do and collecting rent is not a good use of my time.” (IM14)

\section{Theme 2: role demands}

The interviewers asked the respondents to recall different aspects of their role. For the incubator managers, this translated into a perception of what needed to be done. Performing multiple roles and dealing with competing demands appears to be integral to the role of incubator manager. The incubator managers talked at great length about how they were required to perform multiple roles each day. Many described the need to be flexible in order to perform these roles simultaneously. This flexibility could take different forms:

"My role changes from one minute to the next. I go through many hats per day." (IM1)

"Wearing and juggling three or four different hats all at one go isn't fun, but you get used to it and with time you learn how to be flexible in your offering." (IM24)

"I perform multiple roles each day. Being able to switch from lots of different roles requires a high degree of flexibility on my part." (IM36) 
In that regard, managers perceived themselves as having to juggle "multiple roles" to support and meet internal incubator targets:

"There is just one of me... my role requires me to sit in the middle. Half the day I will be helping the entrepreneurs and the other half [I'm] trying to meet my targets... it's a balancing act that requires me to juggle between roles." (IM1)

"My role requires juggling all day long in order to keep my incubatees happy alongside our stakeholders - the people keeping this centre here." (IM16)

With regard to meeting targets, throughout the interviews, the incubator managers referred specifically to the increased pressure in terms of their role. While job creation, innovation and graduation rates were all concerning the incubator manager's role, particularly prominent was the need to increase the incubator occupancy rate to nearly 100 percent, in order to generate income for the business incubator. The following quote is illustrative:

"Occupancy and getting suitable tenants is always a major, as it has been quite difficult in terms of having space to fill and needing to fill the space in order to have the income coming in to cover the costs." (IM32)

It was evident from the interviews we conducted that the managers viewed the pressure to meet occupancy rates as reducing the likelihood of entrepreneurs and businesses from gaining admission to the business incubators. Thus, the criteria of the managers selecting incubatee entrepreneurs appeared to favour those more capable of paying the rent on time, rather than those with high growth potential, which is the real 
aim of business incubation. These comments illustrate a degree of difficulty in attaining a balance between demands towards the incubatee entrepreneurs on the one hand, and towards the structure and targets of the business incubator, on the other, highlighting tensions between the incubator manager's role and related agency. The influence of any group member, including the manager, on collective processes and outcomes depends a great deal on other members of the group (Stewart et al., 2005).

\section{Theme 3: role constraints}

For the incubator managers of the present study, role constraints translated into a perception of "what prevented things from being done." For the incubator managers, three sub-themes emerged: (a) lack of funding and resources; (b) time; (c) red-tape and bureaucracy.

\section{Lack of funding and resources}

The data highlighted that lack of funding and resources represented a core role constraint for the incubator managers in adding value to the incubatee entrepreneurs. The need for managers to constantly seek new funding was crucial, as the majority of them were under increasing pressure to find external grant sources. One manager commented, "It is a cash-starved industry in that you know there's no spare cash floating around - just tight budgets to cope with" (IM38). The incubator managers outlined the complex and time-consuming processes they were undergoing in order to apply for grants, and how this had impacted on their role. For most of the incubator managers, there was a clear sense of responsibility for providing a range of quality resources to their incubatee entrepreneurs. It was disappointing to witness that their accounts demonstrated a high degree of stress and anxiety, due to the limited resources that they had to offer to their incubatee entrepreneurs. Findings also indicated this had distracted them from their core role, and as a result had affected their ability to perform 
their role effectively. The data revealed that a lack of funding was reducing the degree of resources that were readily available to the entrepreneurs.

\section{Time}

It was evident from the incubator managers' discourse that the volume of work requiring their attention did not match the number of hours in a day they dedicated to their role. They were concerned that time pressure was a major constraint on their dayto-day activity, which affected how they performed their role:

"Time is a huge constraint on my day-to-day role. It is all about me balancing time. I need to provide a quality service and make sure that I'm offering them everything that I should be, as well as making sure that we don't stand still in this... bureaucracy working environment." (IM26)

"I'm always too busy. My biggest constraint is managing my time... I just don't have enough hours in the day to complete all my tasks." (IM8)

Emerging across all interviews was that the incubator manager's role was not a traditional Monday-to-Friday, 9-to-5 working week, but instead, an extended one. It was evident that the incubator managers had accepted that this role required longer working hours and multi-tasking. Despite efforts to prioritise, delegate and manage expectations, as discussed later, many respondents mentioned that they still struggle with workload related to competing demands and in order to provide their services at an appropriate level they end up bringing work home. Illustrative are the following quotes: 
“...affects my time and my personal time...I've got many different roles to perform. But I always say the businesses are the most important role I perform so I try always to be available when people need me and if I can't do it in the day, I will do it in the night." (IM33)

"I was editing someone's document at lam in the morning. In this role there's no specific hours.... if I clocked in and out each day it would literally be a joke"(IM38)

Red tape and compliance-related bureaucracy

Related to the issue of finding the time to fulfil multiple roles is the increase in red tape and compliance-related bureaucracy. This emerged consistently as a constraint for many of the incubator managers interviewed. It was evident that this high degree of bureaucracy was preventing them from fully exercising their role. According to the managers:

"There is too much 'red tape' and form filling and it's preventing me from helping the entrepreneurs - the real people that need help." (IM2) "More and more of my time is just wasted in statistical building rather than spending this time with the real entrepreneurs." (IM1)

"Funding is being reduced and we need to make the place sustainable. A big element of my role is reporting on a monthly basis - reporting what is going on with occupancy and different output targets that we have. This is very time-consuming, but it's a must in my role." (IM11)

Others emphasised that having the right mechanisms in place to deal with reporting requirements is essential for minimising the time it consumes but ultimately 
such mechanisms are prescribed by the funding body. As the respondent below puts it:

"I try and minimise it to be honest. We have systems and procedures in place to make sure that it isn't too onerous and that it's limited. Because actually, I appreciate [that] we have to follow this procedure because of the way we've attracted funding. But in terms of how far we go with it does really depend on the funding body." (IM7)

There was a clear sense of frustration captured from the incubator managers that this constraint was hindering them from fulfilling the role for which they were recruited to perform in the first place. Again, it is evident from the data that some business incubators were more target-driven than others.

\section{Theme 4: role choices and performance}

The incubator managers perceived their role choices as what they could do differently and why. Four sub-themes emerged here: (a) prioritising, (b) using experienced staff, (c) managing expectations; (d) building and balancing relationships.

\section{Prioritising}

A constant struggle of choice emerged, as managers needed to prioritise their work against the number of hours in the day. Incubator managers highlighted the significance of being able to prioritise activities related to competing role demands and exercise discretion in determining what they needed to do: 
"It's all about prioritising my workload and knowing what deadlines I need to do first." (IM4)

"Being an incubator manager requires long hours. No two days are the same. You've got to love your job and you've got to be able to prioritise." (IM33)

Many respondents highlighted that their effort should be directed at supporting the incubatee entrepreneurs, rather than pursuing funding as an administration-based, target-driven exercise. From the analysis of our interview data, it became apparent that some business incubators were more target-driven than others, and that this was due to their funding structure. However, even though the incubator managers expressed their dislike and frustration, the majority had accepted it as part of their role and often take priority over business support activities:

"I do think it's an issue...And if we have a choice between doing something very constructive with a client in terms of mentoring and advisory support as opposed to preparing a report, what would you decide to do? I know what I would." (IM30)

"If I don't do the reporting... I won't get the funding. In other words, it's now part of my role. It's a necessary vault unfortunately. If I didn't have to, I could be using my time a lot better in supporting the incubatees." (IM2) 


\section{Delegating to experienced staff}

A substantial number of incubator managers spoke of the value of having experienced staff. They explained in detail how the ability to delegate work, without having to worry about quality or capability, had allowed them to focus on their main role of supporting the incubatee entrepreneurs. The following quotations highlight this point:

"All my staff are very good and highly skilled individuals and it is these people that help me to perform my role well. I couldn't ask for a better team. I don't have to worry if I can go on holiday and leave the centre in their capable hands to look after the incubatees." (IM4)

"It's the experience of my staff that makes a huge difference and adds value to the incubatees... they are the make-up and delivery of the centre. I couldn't perform my role to the degree I do without them." (IM8)

The respondents tended to judge whether new businesses had achieved their potential during the incubation period and whether delegation of business support to staff works. They used personal judgement whilst working alongside these companies: "From this, you obtain a sense of motivation when you observe what you have done has worked." (IM8) Thus, the incubator managers acknowledged and associated performance success with guiding these businesses, individually or collectively with their team, to where they were today: "...they are fully fledged and ready to go and stand on their own two feet and you feel that you were in some small way part of this." (IM22) 


\section{Managing expectations}

It was evident from the in-depth interviews that the incubator managers had to attain a balance between managing their stakeholders/funders' expectations, as well as those of their incubatee entrepreneurs. Achievement of their targets helped them secure funding, which further enabled them to acquire the necessary resources in order to meet incubatee expectations. If managers did not meet expectations (in terms of targets and outputs) from their funding body, they were limited in terms of financial resources to support the incubatee entrepreneurs. Illustrative is the view of the incubator manager below:

"I have been an incubator manager for 30 years and I can honestly tell you the expectations demanded from me now are at least double to what it was...so managing expectations of funders is crucial" (IM11)

From the data analysed, it became apparent that incubatee entrepreneurs' expectations have evolved. The entrepreneurs increasingly expected the incubator managers to spend more time with them on a one-to-one basis, and to deliver better facilities and services. As the following quote illustrates it is important to manage their expectations:

\section{"Incubatee entrepreneurs do expect us 24/7 and as much as I do love my job, I'm only human...So what I'm saying is that it's important to set limits and manage expectations." (IM11)}

The above quotations highlight that the incubator managers had a difficult daily schedule, as their roles were divided between expectations born out of the business incubators' funding structures/stakeholders, on the one hand, and expectations imposed by the incubatee entrepreneurs, on the other. 


\section{Building and balancing relationships}

The incubator managers highlighted the importance and value of building and maintaining a good working relationship between manager and incubatee, but also expressed the importance of not becoming too close to the incubatee entrepreneurs. The incubatees' success is considerably dependent upon this relationship, when a manager understands the entrepreneur's strengths and weaknesses. Table 4 below captures quotations on the need to maintain such a balanced working relationship with the incubatee entrepreneurs, which is demonstrably based on trust and communication.

[Insert Table 4]

Across the case analysis, the findings emphasised key unique and shared perceptions on how the incubator managers perceived their role whilst working through the demands, constraints, and choices. Table 5 below presents a summary of the findings.

[Insert Table 5]

\section{Discussion}

Recognising the high level of risk for start-up firms, alongside the potential benefit of growth and job creation within local communities, governments have developed business incubation to help entrepreneurial firms overcome early stage vulnerability and achieve their goals (Grimaldi and Grandi, 2005). Previous findings have acknowledged the performance of the incubator manager as a key success factor in developing entrepreneurs through business incubation (Hackett and Dilts, 2004; Lalkaka, 2002). More recently, studies drawing on empirical evidence have pointed out that despite the financial investment made, incubators do not always support new jobs or growth of incubated start-ups in other ways (Dvoulety et al., 2018; Lukes, 
Longo and Zouhar, 2019). This raises a point for policy makers as to their expectations regarding business incubation support and associated strategies. In this study, we adopted Stewart's (1982) model in order to unpack the role of incubator managers and the interaction of individual and organisational processes in terms of business incubation, focusing on the management of the business incubation process as the unit of analysis. In so doing, we enriched our understanding of the relational aspects that characterise the previously understated role of the individual incubator manager. Furthermore, this allowed us to convey a more balanced view of incubation management and effectiveness considering the over-emphasis on perspectives of incubate start-ups put by the majority of earlier works in this area.

This research highlighted that the business incubator managers were conscious of the significance of their role in supporting and nurturing the incubatee entrepreneurs. All incubator managers in this study recognised that their primary role was to support the entrepreneurs and displayed personal motivation towards the positive contribution they brought to the incubatee entrepreneurs. It was evident from the data analysis that the respondents have to undertake multiple roles and face conflicting expectations (Katz and Kahn, 1978; Troyer et al., 2000). Porter and Lawler (1968) call these organisational expectations "contextual factors", because they include duties and responsibilities that may be prescribed in a job description, and for which the job-holder is held accountable. Stewart (1982) also asserts that an organisation provides demands with a minimum core of required duties, activities, standards, objectives, and responsibilities that must be met by managers and are usually prescribed in a job description.

Yet, the way they went about managing business incubation and supporting incubatees, and the options taken in that process could be seen as a function of institutional demands, tensions, and often constraints. These incubator managers were 
conditioned by the very institutional structures that had defined their roles. These structures included funding structures, wider institutional settings, such as universities or science parks in which they were based, and other regulatory forces. By adopting Stewart's model of demands-choices-constraints (Stewart, 1982), we have gained insights into three key challenges which characterise the ethos, philosophy, and praxis of incubator managers. Most importantly, these pertain to the sharper contrast between role demands, role constraints, and the influence of wider institutional structures, such as funding structures that regulate the incubation process. Through the interviews that we conducted and analysed, we identified the importance of competitive funding structures that exist in the entrepreneurial ecosystem as a key theme. Operating within this pre-defined set of options, available as a support for enterprise development, was, both an opportunity, as well as a limitation for the incubator managers. This dual perception justified the incubator managers' sense of frustration regarding their capacity to serve the incubatees and hence fulfil their role successfully. Being subject to the market logic of competitive funding structures as part of their operating landscape simultaneously provided the incubator managers with options to move forward, whilst also restraining them in terms of choice, and in having to pursue this funding as a way of reaching out to fulfil both targets and the role of entrepreneur. The mixed nature of revenue streams (i.e. rent, equity, public funds etc.) in traditional type of incubators might be problematic in sustaining the effectiveness of the incubator in the long term. Relying on public funds could be a major flaw; business models of such incubators should incorporate a more refined approach to revenue creation, and this calls for change in respective public policies.

The study reveals that the incubator managers were quite concerned that they were losing the added value of business support (the overarching aim of business 
incubation). In line with prior research that indicates that there is a greater tendency for bureaucratic routines in business incubation environments (Nikolopoulos and Dana, 2017) managers were juggling multiple roles to simultaneously support and meet internal incubator targets. There was a deep sense of frustration from the incubator managers that many barriers existed, mainly target-driven, and that these were often stopping them from fulfilling the key role for which they were recruited in the first place. Overall, incubator managers perceived the business incubator services as target-driven, and as a result, they were under ongoing pressure to meet such targets. They primarily viewed the challenge as balancing the demands and constraints towards the incubatee entrepreneurs on the one side, and the business incubators' funding and target structures on the other. Evidently, some business incubators were more targetdriven than others, which was due to their funding structure. Hence, the funding structure could constitute a constraint on the incubator manager, causing an unwelcomed diversion from core roles. The incubator managers felt strongly that they should direct their time and effort to supporting incubatee entrepreneurs, rather than pursuing red tape defined tasks.

Another key piece of evidence was the issue of dealing with bureaucracy in offering services to incubatee entrepreneurs, a case of conflicting functional demands - "a key concept that underlies much of the reasoning in both strategic management and organizational theory" (Worren, 2018, p. 13). In essence, this affected the managers' agency to substantiate their role in building capacity for entrepreneurs. Reporting on performance evaluation of the business incubator is a case in point. From our data, we observe that one key tension lies in the obligation to report according to a set of requirements for performance, set by wider institutional forces. This could constrain incubator managers' agency, as those performance criteria do not necessarily align with what incubator managers believe their role is or should be. Two related 
observations have to be stated here. First, the multiple role demands of business incubator managers are in conflict with institutional arrangements related to funding structures and reporting mechanisms, which can be seen as constraints. Second, the options that business incubator managers deem as viable for performing their role successfully are determined by the extent to which they experience a conflict between their role demands to support incubatee entrepreneurs and constraining institutional arrangements related to funding structures and reporting to stakeholders. Bearing this in mind, one should be aiming at keeping the structural side of the relationship between competing demands at minimal level (Clegg, Vieira da Cunha and Pina e Cunha, 2004)

Apart from the funding structures and issues related to institutional arrangements, a key challenge that we identified through the research themes pertains to the incubator managers' concept of support. Through analysing the interview material, we identified that support is often extended within a framework of tangible assets and physical location over other forms of support for entrepreneurial venturing. Although it is essential to delineate the business incubator's role in the first place, this kind of support also presents a constraint in terms of the limitation upon additional possibilities for development that the managers could offer to incubatees (cognitive, social, expertise, and knowledge-driven assistance) (Aldrich, 1999; Hansen and Hamilton, 2011; Karatas-Ozkan et al., 2005; Scillitoe and Chakrabarti, 2010; Theodorakopoulos et al., 2014). Analysing the cases studied via the interaction of levels (individual versus organisational) helped to highlight this in a clearer manner, within a framework of flexibility versus control (Kuratko et al., 2011). In alignment with this, interviewed incubator managers in our study have conveyed this notion of shifting functions of their roles i.e. the function of an entrepreneur, a manager and a technician, following Gerber's (2004) typology. Incubator managers should mostly operate at the intersection of entrepreneur and manager, providing vision for the 
incubator as well as strategic and tactical direction, connecting with the network of individuals and organizations in the entrepreneurial ecosystem they are in so that all of this leads to achieving intended goal and objectives.

Notably, role theory considers the enactment of behaviours by individuals in a social encounter, and it is implied that success in a role is dependent on the mastery of such role behaviours (Broderick, 1998). Stewart (1982) holds that the choices made within a role are affected by the demands and constraints that individuals experience. Ultimately, as the analysis revealed, personal views, how the challenges faced are perceived by incubator managers, and the orientation of those with whom they interact play an important role in determining the discretionary nature of their role. The degree of discretion within a specific role is therefore driven by the incumbents' ability to influence the boundaries, responsibilities, and accountabilities of their role (Bowman and Kakabadse, 1997). Common choices in dealing with competing demands and constraints included prioritising tasks, using experienced staff to delegate work and free-up time for business support, managing expectations, and building and balancing relationships with incubatees. Based on the respondents' views, it would appear that designing and implementing better support architectures (including business incubator manager training and development initiatives), formulating better performance management systems that balance process and outcome measures, as well as automating reporting on such measures would be helpful.

\section{Conclusions, recommendations and further research}

In this paper, our focus is on how business incubator managers perceive their own role and performance success in the presence of the challenges and tensions of managing an incubator organisation. Connecting this to the interaction between 
personal (individual agency) and organisational-level processes (institution-building), we have examined the challenges in terms of their perception, and acting whilst working through their role demands, constraints, and choices by applying Stewart's demands and constraints model (1976a; 1976b). Departing from this premise, our study furthers the application of Stewart's theory, with specific application in the field of entrepreneurship and business incubation. Incubator managers are required to reconcile the competing demands and tensions between exploitation and exploration of opportunities (Lubatkin et al., 2006). Living and operating within such tensions inevitably leads to frustrations, and possibly a perception of incomplete or inefficient managerial performance. We agree in this case with Jarzabkowski et al. (2013), who argue that in complex organisational contexts, conflicting demands, interpretations, actions, goals, and notions of success are often present - at the individual, group, or organisational level and their interrelated interactions.

Conceivably, business incubation can continue to be a valuable business support tool for developing entrepreneurs. Nonetheless, policy makers, the Government and local authorities (the funding structure of the business incubator) need to better align the level of performance indicators and compliance requirements currently imposed on the incubator managers with the incubatees' business support needs. Improving support architectures, formulating better performance management systems that balance process and outcome measures and automating performance monitoring would contribute to this effect. Policy makers should be mindful of their expectations about effectiveness of incubation support programmes for start-up development particularly in the context of incubators with mixed revenue streams and operations. This reflective approach entails changes in policy domain as to publicfunding of incubators depending on the nature of their chosen operational mode (e.g. accelerators; co-working spaces; conventional business incubtaors etc.) 
This could allow them to better focus on the individual incubatee entrepreneurs' development needs - in other words, the added value of business incubation, enabling them to simultaneously benefit from different forms of support, such as knowledge and learning, contacts, networking, and mentoring (Hughes et al., 2007). The practice of creating alternative forms of incubation in the form of social hubs, with less emphasis on physical assets and occupancy targets (Nicolopoulou et al., 2015) also supports this argument.

Our approach offers two main contributions to the current knowledge and theorising on business incubation and the role of incubator managers. First, in unpacking the role of incubator manager, we enhance the level of theorising by applying Stewart's role theory and cast light on how incubator managers address competing demands involved in their job roles. Such framing in the context of business incubation stresses the role of managers' agency, not as transactional managers performing routine administrative tasks, but as collaborators and partners, who are themselves embedded in both the organisational and entrepreneurial domains of incubation. Second, we generate managerial implications in the form of recommendations for policy makers and practitioners and highlight the need for formulating support architectures, performance measures and monitoring systems and that pay due regard to process, not just outcomes.

The study suggests that further research is necessary on the constraints facing incubator managers, and what steps they could implement to reduce the negative impact of these obstacles. More generally, our findings could help incubator managers, entrepreneurs, and policy makers reflect upon and understand the challenges they currently face. Following Rasmussen (2011), who argued for a meta-triangulation of theories in order to elucidate complex multi-stage process-based phenomena such as business incubation, we propose that a next level study could be developed by taking 
into consideration the different specific insights from the present study and locating these within a continuum of enterprise development process phases (Anderson and Starnawska, 2008), which could help to paint a richer picture of business incubation. Finally, researchers could develop another stream of research by highlighting the differences between potentially different forms of incubators, following Carayannis and von Zedtwitz (2005), in order to create a typology for locating incubator managers and their perception of their roles and performance success. 


\section{References}

Ahmad, A., 2014, "A mechanisms-driven theory of business incubation". International Journal of Entrepreneurial Behaviour and Research, 20: 375-405.

Albort-Morant, G. and D. Ribeiro-Soriano, 2016, "A bibliometric analysis of international impact of business incubators". Journal of Business Research, 69: 1775-1779.

Aldrich, H., 1999. Organisations Evolving. Thousand Oaks, CA.: Sage Publications Inc.

Allen, D. and E. Bazan, 1990. Value added contribution of Pennsylvania's business incubators to tenant firms and local economies. Pennsylvania: Pennsylvania State University, Smeal College of Business Administration

Al-Mubaraki, H. M. and M. Busler, 2013, "Business incubation as an economic development strategy: a literature review". International Journal of Management, 30: 362-372.

Anderson, A. R. and M. Starnawska, 2008, "Research practices in entrepreneurship: problems of definition, description and meaning". International Journal of Entrepreneurship and Small Business, 9: 221-230.

Autio, E. and M. Klofsten, 1998, “A comparative study of two European business incubators". Journal of Small Business Management, 36: 30-43.

Barratt, M., T. Y. Choi and M. Li, 2011, "Qualitative case studies in operations management: trends, research outcomes and future research implications". Journal of Operation Management, 29: 329-342.

Barrow, C., 2001. Incubators: A Realists Guide to the World's New Business Accelerators. Chichester: John Wiley and Sons Ltd.

Battilana, J., B. Leca and E. Boxenbaum, 2009, "How Actors Change Institutions: Towards a Theory of Institutional Entrepreneurship". Academy of Management Annals, 3: 65-107.

Biddle, B. J. and E. J. Thomas, 1979. Role Theory: Concepts and Research. Huntington, NY: Robert E. Krieger Publishing Co.

Bika, Z. and C. Kalandaridis, 2017, Organizational-Social-Capital, Time and International Family SMEs: An Empirical Study from the East of England, European Management Review, DOI: 10.1111/emre.12160.

Bowman, C. and A. Kakabadse, 1997, "Top Management Ownership of the Strategy Problem”. Long Range Planning, 30: 197-208. 
Broderick, A. J., 1998, "Role theory, role management and service performance". Journal of Services Marketing, 12: 348-361.

Calza, F., L. Dezi, F. Schiavone and M. Simoni, 2014, "The intellectual capital of business incubators". Journal of Intellectual Capital, 15: 597-610.

Carayannis, E. G. and M. von Zedtwitz, 2005, "Architecting gloCal (global-local), real-virtual incubator networks (G-RVINs) as catalysts and accelerators of entrepreneurship in transitioning and developing economies: lessons learned and best practices from current development and business incubation practices". Technovation, 25: 95-110.

Clarysse, B., M. Wright, A. Lockett, E. Van de Velde and A. Vohora, 2005, "Spinning out new ventures: a typology of incubation strategies from European research institutions". Journal of Business Venturing, 20: 183-216.

Crowe, S., K. Cresswell, A. Robertson, G. Huby, A. Avery and A. Sheikh, 2011, "The case study approach". BMC Medical Research Methodology, 11 (100): 19.

De Castro, J. O., S. Khavul and G. D. Bruton, 2014, "Shades of grey: how do informal firms navigate between macro and meso institutional environments?". Strategic Entrepreneurship Journal, 8: 75-94.

Desa, G. and S. Basu, 2013, "Optimization or bricolage? Overcoming resource constraints in global social entrepreneurship". Strategic Entrepreneurship Journal, 7: 26-49.

Duff, A., 2000, "Best practice in business incubator management"; AUSTEP strategic partnering;

http://www.eifn.ipacv.ro/include/documentationsfiles/bestpracrpt.pdf; accessed on 15 January 2013.

Dutt, N., O. Hawn, E. Vidal, A. Chatterji, A. Mcgahan and W. Mitchell, 2016, "How open systems intermediaries address institutional failures: the case of business incubators in emerging market countries". Academy of Management Journal, 59: 818-840.

Dvouletý, O., M. C. Longo, I. Blažková, M. Lukeš, M. Andera, 2018 "Are publicly funded Czech incubators effective? The comparison of performance of supported and non- supported firms". European Journal of Innovation Management, 21: 543-563.

Fondas, N. J. and R. Stewart, 1994, "Enactment in managerial jobs: a role analysis". Journal of Management Studies, 31: 86-103. 
Fry, F. L., 1987, "The role of incubators in small business planning". American Journal of Small Business, 12: 51-61.

Gomm, R., M. Hammersley and P. Foster, 2002. Case Study Method. London: Sage Publications.

Grimaldi, R. and A. Grandi, 2005, "Business incubation and new venture creation: an assessment of incubating models". Technovation, 25: 111-121.

Hackett, S. M. and D. M. Dilts, 2004, "A systematic review of business incubation research". The Journal of Technology Transfer, 29: 55-82.

Hansen, B. and R. Hamilton, 2011, "Factors distinguishing small firm growers and non-growers". International Small Business Journal, 29: 278-294.

Hughes, M., P. Hughes and R. Morgan, 2007, "Exploitative leaning and entrepreneurial orientation alignment in emerging young firms: implications for markets and response performance". British Journal of Management, 18: 359375.

Karatas-Ozkan, M., W. D. Murphy and D. Rae, 2005, "University incubators in the UK”. International Journal of Entrepreneurship and Innovation, 6: 401-421.

Katz, D. and R. L. Kahn, 1978. The Social Psychology of Organizations, 2nd ed. New York: Wiley.

Kroeck, K. G., 2003, "Rosemary Stewart on management: behavioural scribe, squire of theory, pragmatic scientist". In K.B. Lowe (ed.) "Demands, constraints, choices and discretion: an introduction to the work of Rosemary Stewart". The Leadership Quarterly, 14: 193-238.

Kuratko, D., M. Morris and J. Covin, 2011. Corporate Innovation and Entrepreneurship, 3rd ed. US: South Western.

Lalkaka, R., 2002, "Technology business incubators to help build on innovationbased economy". Journal of Change Management, 3: 167-176.

Lubatkin, M. H., Z. Simsek, Y. Ling and J. F. Veiga, 2006, "Ambidexterity and performance in small - to medium-sized firms: The pivotal role of top management team behavioral integration". Journal of Management, 32: 646672.

Lukeš, M., M. C. Longo and J. Zouhar, 2019. "Do business incubators really enhance entrepreneurial growth? Evidence from a large sample of innovative Italian startups". Technovation, 82, 25-34. 
McAdam, M. and S. Marlow, 2007, "Building futures or stealing secrets? Entrepreneurial cooperation and conflict with business incubators". International Small Business Journal, 25: 361-382.

Meru, A. K. and M. Struwig, 2015, "Business-incubation process and business development in Kenya: Challenges and recommendations". Journal of Entrepreneurship and Innovation in Emerging Economies, 1: 1-17.

Miles, M. B. and A. M. Huberman, 1994. Qualitative Data Analysis. London: Sage Publications.

Mullins, L. J., 2002. Management and Organisational Behaviour. Harlow: Pearson Education Limited.

Nikolopoulos, K. P. and L. P. Dana, 2017, "Social capital formation in EU ICT SMEs: The role played by the mobility of knowledge workers". European Management Review, 14: 409-422.

Nicolopoulou, K., M. Karatas- Ozkan, M. Nummann and C. Vas, 2015, "An incubation perspective on social innovation: the London Hub as a social". $R \& D$ Management, 47: 368-384.

Patton, D., 2014, "Realising potential: the impact of business incubation on the absorptive capacity of new technology-based firms". International Small Business Journal, 32: 897-917.

Petrovic, J., 2008, "Unlocking the role of a board director: a review of the literature". Management Decision, 46: 1373-1392.

Phan, P. H., D. S. Siegel and M. Wright, 2005, "Science parks and incubators: Observations, synthesis and future research". Journal of Business Venturing, 20: 165-182.

Porter, L. W. and E. E. Lawler, 1968. Managerial attitudes and performance. Homewood, IL: Irwin.

Prokopenko, J. and I. Pavlin, 1991. Entrepreneurship Development in Public Enterprise. Geneva: International Labour Office.

Rasmussen, E., 2011, "Understanding academic entrepreneurship: exploring the emergence of university spin-off ventures using process theories". International Small Business Journal, 29: 448-471.

Rothaermel, F. and M. Thursby, 2005, "Incubator firm failure or graduation? The role of university linkages". Research Policy, 34: 1076-1090. 
Rouach, D., S. Louzoun, and F. Deneux, 2010. Incubators of the World Best Practices from Top Leaders USA, Israel, France, Switzerland, China and Japan. Paris, France: Pearson Education.

Scillitoe, J. and A. Chakrabarti, 2010, "The role of incubator interactions in assisting new ventures". Technovation, 30: 155-167.

Sherman, H. D., 1999, "Assessing the intervention effectiveness of business incubation programs of new business start-ups". Journal of Developmental Entrepreneurship, 4: 117-133.

Shivers-Blackwell, S. L., 2004, "Using role theory to examine determinants of transformational and transactional leader behaviour". Journal of Leadership and Organizational Studies, 10: 41-50.

Siegel, D. and M. Wright, 2015, “Academic entrepreneurs: time for a rethink?”. British Journal of Management, 26: 582-595.

Stewart, G. L., I. S. Fulmer and M. R. Barrick, 2005, “An exploration of member roles as a multilevel linking mechanism for individual traits and team outcomes". Personnel Psychology, 58: 343-65.

Stewart, R., 1976a. Contrasts in Management: A Study of Different Types of Managers' Jobs, their Demands and Choices. London: McGraw-Hill.

Stewart, R., 1976b, "To understand the manager's job: consider demands, constraints, choices". Organisational Dynamics, 4: 22-32.

Stewart, R., 1982, “A model for understanding jobs and behaviour". Academy of Management Review, 7: 7-13.

Stewart, R., 1997. The Reality of Management. Oxford: Butterworth- Heinemann.

Stewart, R., 2003, "Woman in a man's world". In K.B. Lowe (ed.), "Demands, constraints, choices and discretion: an introduction to the work of Rosemary Stewart". The Leadership Quarterly, 14: 193-238.

Theodorakopoulos, N., N. Kakabadse and C. McGowan, 2014, "What matters in business incubation? A literature review and suggestion for situated theorising". Journal of Small Business and Enterprise Development, 21: 602622.

Tocher, N., S. L. Oswald and D. J. Hall, 2015, "Proposing social resources as the fundamental catalyst toward opportunity creation". Strategic Entrepreneurship Journal, 9: 119-135. 
Troyer, L., C. W. Mueller and P. I. Osinsky, 2000, "Who's the boss?: A roletheoretic analysis of customer work". Work and Occupations, 27: 406-427.

Udell, G. G., 1990, “Are business incubators really creating new jobs by creating new businesses and new products?". Journal of Product Innovation Management, 7: 108-122.

Willcocks, S., 1994, "The clinical director in the NHS: utilising a role-theory perspective". Journal of Management in Medicine, 8: 68-76.

Wonglimpiyarat, J., 2016, "The innovation incubator, university business incubator and technology transfer strategy: The case of Thailand". Technology in Society, 46: $18-27$.

Worren, N., 2018, "Operationalizing the concept of conflicting functional demands". European Management Review, DOI: 10.1111/emre.12173.

Zhang, H., W. Q. Wu and L. M. Zhao, 2016, “A study of knowledge supernetworks and networks robustness in different business incubator". Physica A: Statistical Mechanics and its Application, 447: 545-560.

Table 1. Research population by region.

\begin{tabular}{|l|l|} 
Region & $\begin{array}{c}\text { Incubator } \\
\text { Manager }\end{array}$ \\
\hline R1 & 5 \\
\hline R2 & 5 \\
\hline R3 & 5 \\
\hline R4 & 5 \\
\hline R5 & 5 \\
\hline R6 & 5 \\
\hline R7 & 5 \\
\hline
\end{tabular}




\begin{tabular}{|ll|}
\hline R8 & 5 \\
\hline Total & 40 \\
\hline
\end{tabular}


Table 2. Thematic framework.

(1) Role - Exploring the incubator manager's perceived role.

(2) Demands - What do incubator managers need to do?

\section{(3) Constraints - What} prevents incubator managers from doing things?
(4) Choices - What can incubator managers do differently and why?

(5) Performance Success - The incubator manager's expectations

Source: Compiled by the authors

Table 3. How incubator managers perceived their role.

\begin{tabular}{|l|l|}
\hline Categories & \multicolumn{1}{|c|}{ Illustrative Examples } \\
\hline Mentor & $\begin{array}{l}\text { "I oversee all the development, facilities and the incubation } \\
\text { programme alongside the management of the incubator. I'm also a } \\
\text { mentor and an advisor. I'm doing everything possible to support the } \\
\text { incubatees." (IM3) }\end{array}$ \\
\hline $\begin{array}{l}\text { A sign } \\
\text { poster / } \\
\text { role }\end{array}$ & $\begin{array}{l}\text { "Myprole is very much a signposting role- it's primarily around } \\
\text { "It's about being there to signpost and support as well as covering } \\
\text { the whole landlord side of looking after the building." (IM22) } \\
\text { "I see my role like the first port of call. Sometimes the things they } \\
\text { come to you with are huge, and then other times they are quite } \\
\text { trivial." (IM31) }\end{array}$
\end{tabular}




\begin{tabular}{|l|l|}
\hline A catalyst & $\begin{array}{l}\text { "I perceive my role very much as the catalyst for all the companies." } \\
\text { (IM36) }\end{array}$ \\
\hline
\end{tabular}

Source: Compiled by the authors

Table 4. Managers' quotations on building a balanced working relationship.

\begin{tabular}{|l|l|}
\hline Categories & Illustrative Examples \\
\hline Best friend & $\begin{array}{l}\text { "I think it can become dangerous because they can make the assumption that } \\
\text { they're your mate... you will help... we haven't paid the rent, but it will be } \\
\text { alright because I'm mates with the incubator manager."(IM4) } \\
\text { "It's all about being their best friend when they want you to be, but also } \\
\text { being their most prolific critic when you have to be as well." (IM5) }\end{array}$ \\
\hline Priend & $\begin{array}{l}\text { "I think if a decision needs to be taken, regardless to what it is, they see me } \\
\text { about having that balance." (IM1) }\end{array}$ \\
\hline Critical \\
friend & $\begin{array}{l}\text { "As a critical friend I always operate an open door policy." (IM8) } \\
\text { "I think they see me as a critical friend who they would put trust in and } \\
\text { hopefully they would see me as someone who would seek to act in their best } \\
\text { interest and identify support opportunities that would help their business. } \\
\text { [They would also see me] as someone who is prepared to listen and talk } \\
\text { through the issues that they are facing and give them honest feedback." } \\
\text { (IM7) }\end{array}$ \\
\hline
\end{tabular}

Source: Compiled by the authors 
Table 5. Summary of findings

\begin{tabular}{|l|l|l|l|l|l|l|l|}
\hline Role & Case & Case & Case & Case & Case & Case & Case \\
Demands & study & Study & Study & Study & Study & Study & Study \\
& 1,8, & $2,10,11$, & $3,13,14$, & $4,18,19$, & $5,20,21$, & 6,22, & 7,24, \\
& 9,15, & 12,17 & 29,30 & 28,31 & 37,38 & & \\
& 16, & & & & & & \\
\hline
\end{tabular}




\begin{tabular}{|c|c|c|c|c|c|c|c|}
\hline & $\begin{array}{l}27, \\
33, \\
35, \\
36,40\end{array}$ & & & & & $\begin{array}{l}23,32, \\
34\end{array}$ & $\begin{array}{l}25,26, \\
39\end{array}$ \\
\hline $\begin{array}{l}\text { Performing } \\
\text { Multiple }\end{array}$ & Yes & Yes & No & Yes & Yes & Yes & Yes \\
\hline $\begin{array}{l}\text { Managing } \\
\text { Expectations }\end{array}$ & Yes & Yes & Yes & No & Yes & No & Yes \\
\hline $\begin{array}{l}\text { Building and } \\
\text { Balancing } \\
\text { Relationships }\end{array}$ & Yes & Yes & No & Yes & Yes & No & Yes \\
\hline $\begin{array}{l}\text { Occupancy } \\
\text { and Finding } \\
\text { Suitable } \\
\text { Candidates }\end{array}$ & Yes & Yes & No & Yes & Yes & Yes & No \\
\hline $\begin{array}{l}\text { Role } \\
\text { Constraints }\end{array}$ & & & & & & & \\
\hline $\begin{array}{l}\text { Lack of } \\
\text { Funding and } \\
\text { Resources }\end{array}$ & Yes & Yes & Yes & Yes & Yes & Yes & No \\
\hline Time & Yes & Yes & Yes & No & Yes & Yes & Yes \\
\hline
\end{tabular}




\begin{tabular}{|c|c|c|c|c|c|c|c|}
\hline $\begin{array}{l}\text { Red tape and } \\
\text { Bureaucracy }\end{array}$ & Yes & Yes & Yes & Yes & No & No & Yes \\
\hline \multicolumn{8}{|l|}{ Role Choices } \\
\hline Priorities & Yes & No & No & Yes & No & Yes & Yes \\
\hline $\begin{array}{l}\text { Experienced } \\
\text { Staff }\end{array}$ & Yes & No & No & Yes & Yes & Yes & Yes \\
\hline
\end{tabular}

Source: Compiled by the authors 
Figure 1. The geographic locations in the UK.

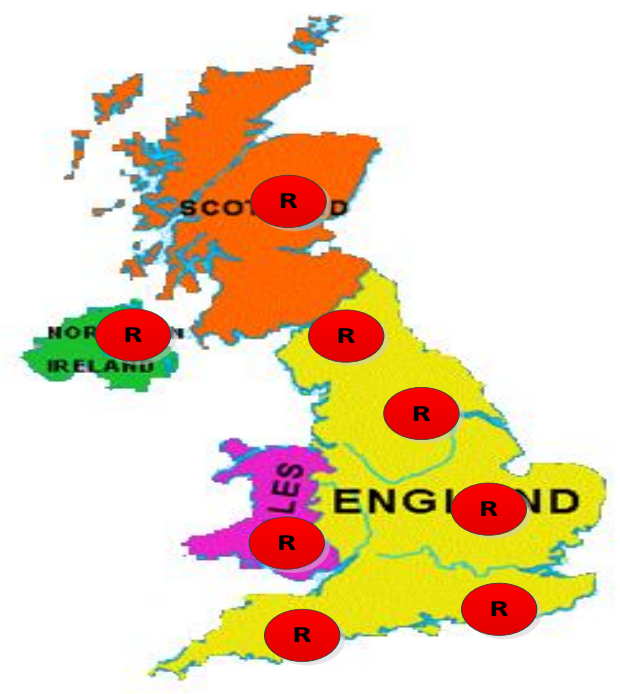

Source: Compiled by the authors

Figure 2. Assessing success.

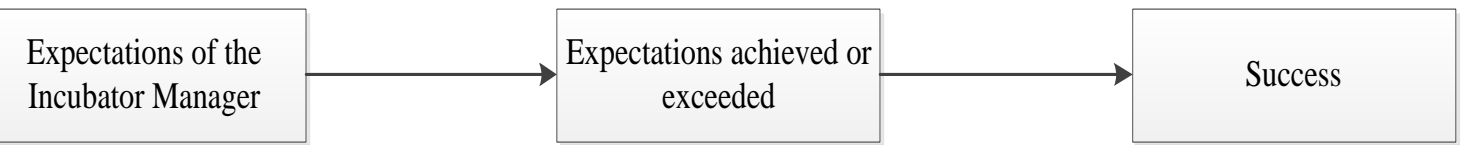

Source: Compiled by the authors 
